\title{
Giant Congenital Melanocytic Nevi (GCMN): Sebuah Laporan Kasus Langka
}

\author{
Erico Lemuel Yonathan ${ }^{1 *}$, Hari Darmawan ${ }^{2}$ \\ Klinik Raycare Jakarta ${ }^{1}$ \\ Bagian Ilmu Kesehatan Kulit dan Kelamin, Fakultas Kedokteran Universitas \\ Tarumanagara Jakarta ${ }^{2}$ \\ *e-mail: ericolemuel@gmail.com
}

\begin{abstract}
Abstrak
Giant Congenital Melanocytic Nevi (GCMN) adalah nevus yang timbul saat lahir atau minggu pertama kehidupan. Insiden GCMN diperkirakan terjadi kurang dari 1:20.000 kelahiran. Lesi berupa bercak hitam atau kecoklatan dengan batas abnormal, datar atau menimbul dari permukaan, dan bisa terdapat hipertrikosis. Giant Congenital Melanocytic Nevi (GCMN) bisa berhubungan dengan terjadinya melanoma maligna dan neurocutaneous melanocytosis. Pada laporan kasus ini dilaporkan seorang bayi laki-laki dengan bercak kehitaman yang tumbuh rambut diatasnya, berukuran besar dengan bentuk tidak beraturan di kepala sebelah kiri sejak lahir. Pasien lahir pervaginam, cukup bulan, dan berat badan lahir cukup. Pasien lahir dari ibu P2A0 tanpa riwayat konsumsi obat dan riwayat penyakit saat kehamilan. Dalam pemantauan selama 3 tahun, terdapat bercak hitam multipel, berukuran lebih kecil di kaki kanan dan kiri depan, dan punggung. Terapi GCMN meliputi prosedur operasi dan non-operasi, dukungan psikis, dan pemantauan seumur hidup. Pada kasus ini perlu dilakukan pemeriksaan dan observasi lebih lanjut.
\end{abstract}

Kata Kunci: giant congenital melanocytic nevi, melanoma maligna, neurokutaneus melanositosis

\section{Giant Congenital Melanocytic Nevi (GCMN): A Rare Case Report}

\begin{abstract}
Giant Congenital Melanocytic Nevi (GCMN) is a nevus which present at birth or arise within the first few weeks of life. Incidence of GCMN is estimated at below 1:20.000 newborns. Lesion of GCMN usually appears with a black or brownish plaque and may have abnormal borders, flat or protruding surface and hypertrichosis. Giant Congenital Melanocytic Nevi (GCMN) is associated with malignant melanoma and neurocutaneous melanocytosis. A male newborn baby is reported to have a giant black hairy plaque, with irregular shape in his head since born. Patient was born naturally, full term, and normal birth weight. The mother has no medication consumption and disease history during pregnancy. In our three years follow up, there are multiple black patches with smaller size in front right and left leg, and the back of the body. The GCMN treatment consists of surgical and non-surgical procedures, psychological support, and lifelong monitoring. In this case, further examination and observation are needed.
\end{abstract}

Keywords: giant congenital melanocytic nevi; malignant melanoma; neurocutaneous melanocytosis 


\section{PENDAHULUAN}

Congenital Melanocytic Nevi (CMN) adalah nevus yang timbul saat lahir atau minggu pertama kehidupan. Congenital Melanocytic Nevi (CMN) merupakan proliferasi sel melanosit kutan yang timbul di epidermis, dermis, atau jaringan lain (Abubakar et al, 2018; Sakhiya et al, 2020; Wu et al, 2020). Congenital Melanocytic Nevi (CMN) terjadi sangat langka, yaitu sebesar 1\% dari kelahiran hidup (Griffiths et al, 2016; Viana et al, 2013). Insiden kasus Giant Congenital Melanocytic Nevi (GCMN), yang merupakan CMN berdiameter lebih dari $20 \mathrm{~cm}$, terjadi kurang dari 1:20.000 kelahiran. Giant Congenital Melanocytic Nevi (GCMN) timbul saat lahir dan berkembang sesuai tubuh secara proporsional (Abubakar et al, 2018; James et al, 2016; Viana et al, 2013; Wolff et al, 2013; Wu et al, 2020).

Gambaran klinis CMN berupa lesi berwarna coklat kehitaman dengan batas abnormal, datar atau menimbul dari permukaan, dan terdapat hipertrikosis diatasnya. Lesi paling banyak ditemukan di badan, terutama di bagian atas atau bawah punggung. Gambaran khasnya dapat berupa "cape", "bathing trunk", "tippet", atau "garment", sesuai dengan distribusinya (Balomenou et al, 2019; Endomba et al, 2018; James et al, 2016; Sakhiya et al, 2020; Viana et al, 2013; Wolff et al, 2013). Sebanyak 75\% kasus CMN didapatkan lesi kecil dan multipel yang disebut lesi satelit. Lesi ini dapat timbul saat lahir atau saat tahun pertama kehidupan. Jika lesi tersebut lebih dari 20, biasanya berhubungan dengan kelainan neurologik (Abubakar et al, 2018; Balomenou et al, 2019; Endomba et al, 2018; Griffiths et al, 2016; Habif, 2004).

Giant Congenital Melanocytic Nevi (GCMN) memiliki risiko tinggi untuk timbulnya komplikasi, seperti melanoma maligna, neurofibroma, lipoma, dan keterlibatan sistem saraf (Sakhiya et al, 2020). Pada pasien GCMN, risiko perubahan menjadi melanoma cukup tinggi, yaitu sebesar 5-10\% (Viana et al, 2013; Wu et al, 2020). Selain keganasan, pasien dengan GCMN perlu diperiksa secara berkala terkait gangguan neurologik dan psikososial. Neurocutaneous Melanocytosis (NCM) dijumpai pada pasien GCMN yang memiliki lesi di area kepala, leher, area paravertebral (bathing-trunk nevi), atau GCMN dengan beberapa lesi satelit. Neurocutaneous Melanocytosis (NCM) ditandai dengan adanya melanosis abnormal di sistem saraf pusat. Terapi GCMN meliputi prosedur operasi dan non-operasi, dukungan psikis, dan pemantauan seumur hidup (Balomenou et al, 2019; Habif, 2004; Meshram et al, 2018). 


\section{PRESENTASI KASUS}

Seorang bayi laki-laki dilaporkan memiliki bercak kehitaman yang tumbuh rambut diatasnya dengan ukuran kurang lebih 5\% dari area kepala, dengan bentuk tidak beraturan di kepala sebelah kiri sejak lahir. Bayi lahir pervaginam, cukup bulan, dengan berat badan lahir 3200 gram. Pasien merupakan anak ke-2. Ibu pasien dalam kondisi sehat, tidak ada penyulit saat kehamilan dan tidak mengonsumsi obatobatan tertentu saat kehamilan. Nutrisi ibu pasien saat kehamilan baik, ibu pasien rutin melakukan kontrol ke bidan. Tidak ada keluarga pasien yang mengalami keluhan serupa. Status generalikus pasien dalam batas normal. Status dermatologikus pada regio frontotemporal sinistra didapatkan plak hiperpigmentasi, soliter, bentuk iregular, berukuran lebih dari $20 \mathrm{~cm}$, diskret, terdapat hipertrikosis di atas permukaan lesi, dan tidak terdapat lesi satelit (Gambar 1).

Pada saat pasien berusia 3 tahun, dilakukan kembali pemeriksaan pada lesi kulit pasien. Keluarga pasien mengeluh terdapat lesi kulit yang ukurannya lebih kecil di kaki kanan dan kiri depan, serta punggung. Keluarga pasien tidak mengetahui persis mana lesi tambahan yang timbul terlebih dahulu.

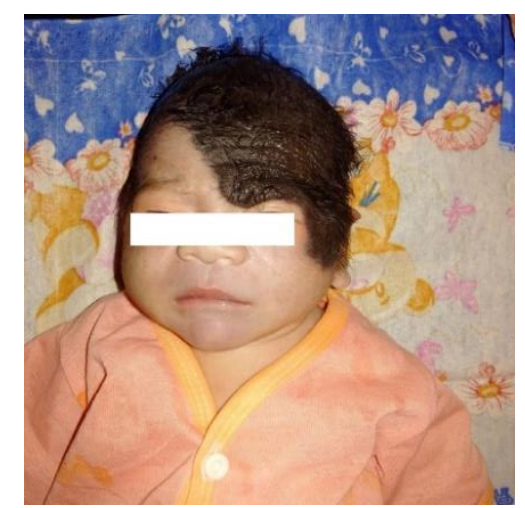

Gambar 1. Lesi frontotemporal sinistra saat pasien baru lahir

Lesi kulit di kepala membesar sesuai dengan pertumbuhan pasien (Gambar 2AB.) Pasien tidak mengeluhkan gatal pada lesinya. Status dermatologikus pada regio dorsal, kruris anterior dextra dan sinistra didapatkan makula hiperpigmentasi, multipel dengan lesi satelit, bentuk iregular, ukuran bervariasi dengan diameter \pm 1 hingga $5 \mathrm{~cm}$, diskret, terdapat hipertrikosis pada sebagian lesi (Gambar 3A-C). Perlu dilakukan pemeriksaan lebih lanjut pada lesi kulit pasien, dan dilakukan pemantauan terhadap adanya risiko melanoma maligna dan neurokutaneus melanositosis. 

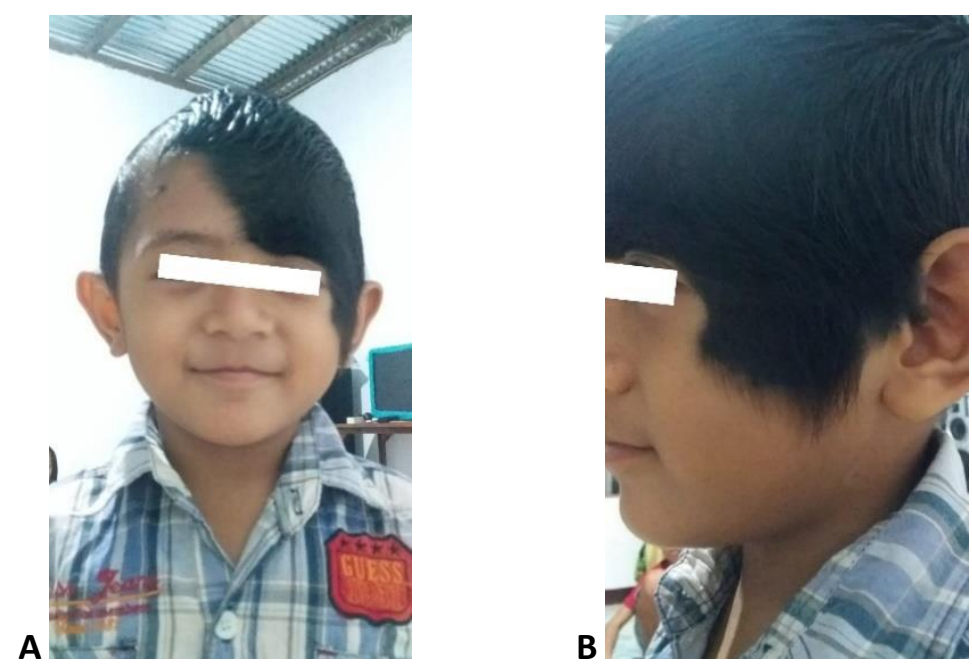

Gambar 2. Lesi frontotemporal sinistra saat pasien berusia 3 tahun. A) Tampak depan. B) Tampak samping

A

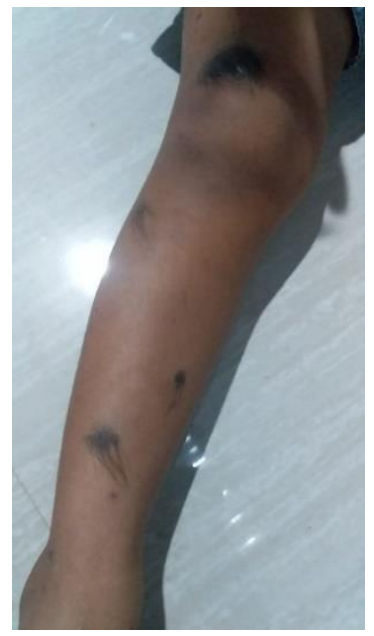

B

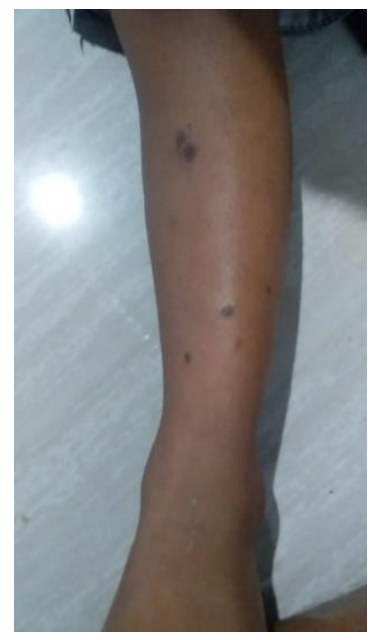

C

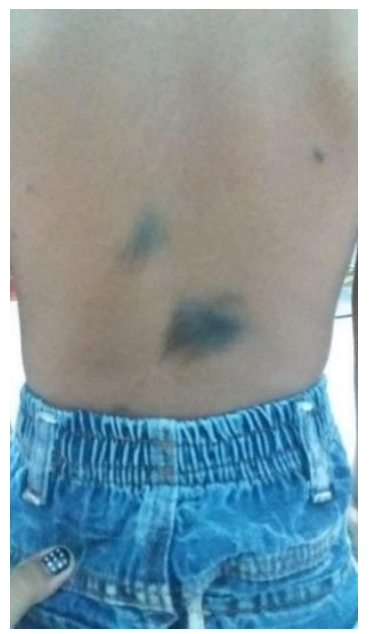

Gambar 3. Lesi satelit saat pasien berusia 3 tahun. A) Pada kaki kanan depan. B) Pada kaki kiri depan. C) Pada punggung

\section{PEMBAHASAN}

Congenital Melanocytic Nevi (CMN) adalah lesi kulit neoplasma melanositik yang berpigmen, umumnya timbul sejak lahir, dan bisa berkembang seiring bertambahnya usia. Berdasarkan ukuran, CMN dibagi menjadi tiga, yaitu kecil $(<1,5$ $\mathrm{cm})$, sedang $(1,5-19,9 \mathrm{~cm})$, dan besar $(>20$ cm) (Araujo et al, 2015; Endomba et al, 2018; Jewargikar et al, 2015; Sakhiya et al,
2020; Wolff et al, 2012; Wolff et al, 2013; $\mathrm{Wu}$ et al, 2020). Ukuran lesi tersebut bergantung pada letak anatomisnya. Seorang pasien bisa dikatakan giant CMN jika lesinya sebesar telapak tangan jika mengenai area kepala dan leher (atau dua kali lebih besar untuk area anatomis lain), $30 \%$ luas permukaan tubuh, atau $900 \mathrm{~cm}^{2}$ pada dewasa (atau lebih rendah jika melibatkan area anatomi mayor) (Wolff et 
al, 2012). Pada kasus ini, lesi kulit pada regio frontotemporal sinistra timbul sejak lahir dan termasuk dalam kategori giant $\mathrm{CMN}$, dimana ukurannya lebih besar dari telapak tangan, dan $30 \%$ luar permukaan tubuh, sehingga mendukung diagnosis GCMN. Sedangkan lesi kulit di daerah kaki kanan dan kiri depan, serta punggung termasuk lesi satelit yang bervariasi dari CMN kecil hingga sedang.

Giant Congenital Melanocytic Nevi (GCMN) pertama kali ditemukan oleh Rokitanski pada tahun 1861 pada remaja putri dengan hidrosefalus dan retardasi perkembangan. Setelah pasien tersebut meninggal, didapatkan melanositosis (Balomenou et al, 2019). Lesi pada GCMN berwarna coklat kehitaman dengan batas abnormal, datar atau menimbul dari permukaan, dan terdapat hipertrikosis diatasnya. Gambaran khasnya dapat berupa "cape", "bathing trunk", "tippet", atau "garment", sesuai dengan distribusinya. Giant Congenital Melanocytic Nevi (GCMN) dapat mengenai area tubuh mana saja, namun paling sering area badan (Balomenou et al, 2019; Endomba et al, 2018; James et al, 2016; Sakhiya et al, 2020; Viana et al, 2013). Sebanyak 75\% kasus $\mathrm{CMN}$ didapatkan lesi kecil dan multipel yang disebut lesi satelit dan timbul saat lahir atau saat tahun pertama kehidupan. Jika jumlah lesi satelit lebih dari 20, biasanya berhubungan dengan kelainan neurologik (Abubakar et al, 2018; Balomenou et al, 2019; Endomba et al, 2018; Griffiths et al, 2016; Habif, 2004). Pada kasus ini, didapatkan lesi satelit di kaki kanan dan kiri depan, serta punggung dengan ukuran bervariasi. Lesi GCMN bersifat asimptomatik, namun sebagian pasien mengeluhkan rasa gatal dan xerosis (Endomba et al, 2018; Sakhiya et al, 2020; Viana et al, 2013). Pada pasien dalam kasus ini, dalam anamnesis lanjutan saat berusia 3 tahun, pasien tidak mengeluh adanya rasa gatal pada lesi kulitnya.

CMN dimulai saat usia kehamilan ke 5 hingga 24 minggu (Viana et al, 2013). Mutasi genetik merupakan faktor yang paling berperan dalam patogenesis terjadinya CMN. Pada CMN, terutama yang berukuran sedang dan giant, didapatkan adanya mutasi NRAS dan BRAF. Gen NRAS melakukan sintesis protein $\mathrm{N}$-Ras yang berperan penting dalam mengatur perkembangan sel. Mutasi pada gen ini akan mengakibatkan kesalahan morfologi neuroektoderma sehingga timbul pertumbuhan tidak terkontrol dari melanoblast, yang merupakan sel prekursor dari melanosit (Endomba et al, 2018; Griffiths et al, 2016; Meshram et al, 2018; Sakhiya et al, 2020; Wolff et al, 2012). Secara molekuler, perkembangan melanosit dikontrol oleh proto-onkogen c-met dan c- 
kit. Hepatocyte Growth Factor (HGF) adalah regulator sitokin dari sel epitel yang mengekspresikan tyrosine kinase yang dikode oleh c-met. Ekspresi berlebihan dari faktor ini akan menyebabkan kelainan diferensiasi, proliferasi, dan migrasi sel melanosit, dan bisa berhubungan dengan terjadinya GCMN (Endomba et al, 2018; Meshram et al, 2018; Sakhiya et al, 2020; Viana et al, 2013).

Secara histologis, GCMN memiliki gambaran yang mirip dengan nevus didapat lainnya. Keterlibatan epidermis berupa hiperkeratosis dan hiperplasia, elongasi rete ridges dengan peningkatan jumlah melanosit dan hiperpigmentasi dapat dijumpai (Endomba et al, 2018; Viana et al, 2013). Giant Congenital Melanocytic Nevi (GCMN) dapat dibedakan dengan nevus didapat lain dari keterlibatannya pada lapisan dalam dermis, subkutan, fasia, otot, dan struktur di sekitarnya. Sel nevus ditemukan dalam distribusi patchy perivascular, dan dapat ditemukan diantara serabut kolagen (Abubakar et al, 2018; Griffiths et al, 2016; Habif, 2004; James et al, 2016; Viana et al, 2013; Wolff et al, 2012; Wolff et al, 2013). Kultur dari melanosit menunjukan adanya perubahan yang melibatkan kromosom 1p, 12p, dan 19p (Jewargikar et al, 2015). Dermoskopi dapat digunakan untuk membantu diagnosis GCMN. Gambaran dermoskopi yang sering ditemukan adalah globular $(79,7 \%)$, anyaman retikuler $(70,3 \%)$, hipertrikosis (68,9\%), milia-like cysts (52,7\%), dan hipopigmentasi perifolikuler (32,4\%) (Habif, 2004).

Giant Congenital Melanocytic Nevi (GCMN) dapat menimbulkan beberapa penyulit pada pasien, salah satunya yaitu dampak secara psikososial yang dapat menimbulkan penarikan diri secara sosial. Penyulit lainnya yang harus diperhatikan adalah keganasan. Lesi yang bertambah besar, nyeri, timbul pendarahan, ulserasi, perubahan warna, dan menjadi gatal, patut dicurigai sebagai keganasan (Endomba et al, 2018; Sakhiya et al, 2020; Wolff et al, 2012). Pada pasien ini tidak ditemukan adanya keluhan-keluhan tersebut, namun terdapat lesi satelit pada pemantauan tiga tahun kehidupan pasien. Hal tersebut harus dilakukan pemantauan lebih lanjut apakah ada perubahan menjadi melanoma. Risiko perkembangan GCMN menjadi melanoma dilaporkan berkisar antara 5-10\% (Viana et al, 2013; Wu et al, 2020). Perkembangan GCMN menjadi melanoma lebih sering ditemukan pada 3 hingga 5 tahun pertama kehidupan (Wolff et al, 2012).

Komplikasi GCMN lainnya adalah neurocutaneous melanocytosis (NCM) yang ditandai dengan adanya melanosis abnormal di sistem saraf pusat. Neurocutaneous melanocytosis (NCM) lebih 
banyak dijumpai pada pasien GCMN yang memiliki lesi di area kepala, leher, area paravertebral (bathing-trunk nevi), atau GCMN dengan beberapa lesi satelit (Balomenou et al, 2019; Habif, 2004; James et al, 2016; Meshram et al, 2018; Sakhiya et al, 2020; Viana et al, 2013; Wolff et al, 2012). Pada kasus ini, pasien memiliki risiko untuk mendapatkan NCM, karena lokasi lesi GCMN pada area kepala dan terdapat lesi satelit di tangan kanan depan, tangan kiri depan, dan punggung. Pasien dengan NCM bisa simptomatik atau asimptomatik. Gejala NCM biasanya timbul pertama kali sebelum usia 3 tahun, berupa peningkatan tekanan intrakranial, kejang, hidrosefalus, kelumpuhan saraf kranialis, hemiparesis, dan keterlambatan perkembangan. Gejala berikutnya dapat ditemukan pada dekade dua atau tiga, dengan keluhan nyeri kepala dan gangguan neuropsikiatri (Araujo et al, 2015; Balomenou et al, 2019; Griffiths et al, 2016; Meshram et al, 2018; Viana et al, 2013). Pada kasus ini tidak ada gejala NCM, namun karena NCM bisa asimptomatik, pasien tetap berisiko mengalami NCM, mengingat lesi GCMN terdapat di kepala.

Kadonaga dan Frieden melaporkan kriteria diagnosis NCM berupa adanya satu GCMN, tiga atau lebih CMN, yang berhubungan dengan melanosis meningeal atau melanoma meningeal, tidak adanya melanoma kutaneus, kecuali pada pasien yang lesi meningealnya jinak secara histologis, tidak adanya melanoma meningeal, kecuali pada pasien dengan lesi kulit yang secara histologis terbukti jinak (Araujo et al, 2015; Viana et al, 2013). Pada pasien belum dilakukan pemeriksaan secara histologis, neurologis, dan radiologis lebih lanjut seperti MRI karena adanya keterbatasan biaya.

Hal-hal yang harus diperhatikan secara individual dalam melakukan penanganan GCMN adalah umur pasien, ukuran dan lokasi lesi, risiko melanoma, kemungkinan adanya NCM, terdapat perubahan pada lesi, risiko fungsional yang timbul dari prosedur invasif, aspek psikologis yang berhubungan dengan CMN atau bekas operasi. Penanganan GCMN meliputi prosedur operasi atau non-operasi, penanganan psikologis, dan memperhatikan pada perubahan warna dan permukaan dari lesi (Endomba et al, 2018; Jewargikar et al, 2015; Meshram et al, 2018; Sakhiya et al, 2020; Viana et al, 2013). Prosedur operasi GCMN meliputi reseksi serial, bedah eksisi dengan skin graft, dan penggunaan tissue expander yang diikuti dengan reseksi (James et al, 2016; Jewargikar et al, 2015; Meshram et al, 2018). Tindakan bedah eksisi profilaksis dapat dilakukan dengan asumsi bahwa melanoma dapat timbul pada lesi nevus tersebut. Tindakan tersebut tidak pasti 
menghilangkan kemungkinan keganasan, namun diharapkan mengurangi insidensi terjadinya keganasan dengan berkurangnya sel melanosit (James et al, 2016; Viana et al, 2013). Pada kasus ini, belum ada tindakan pada pasien dengan alasan keterbatasan biaya. Pengobatan secara oral ataupun topikal juga tidak diberikan karena tidak sesuai dengan standar terapi GCMN dan perlu penelitian lebih lanjut.

Hong et al (2019) melakukan penelitian untuk menilai efektifitas metode bedah plastik untuk menangani 20 pasien dengan total 44 lesi GCMN yang dilakukan pemantauan dalam 10 hari dan 6 bulan setelah operasi. Dari penelitian tersebut dapat disimpulkan bahwa metode bedah plastik yang digunakan paling banyak adalah bedah eksisi serial, skin graft, dan tissue expansion, dan masing-masing metode tersebut terbukti efektif untuk menangani kasus GCMN. Dari pemantauan penelitian tersebut didapatkan bahwa $81 \%$ pasien memiliki hasil yang baik dan 19\% memiliki hasil yang cukup untuk metode bedah skin graft. Sebanyak $83 \%$ pasien memiliki hasil yang baik dan $17 \%$ memiliki hasil yang cukup untuk metode tissue expansion. Tidak ada kasus yang memiliki hasil yang buruk dalam pemantauan tersebut.

Pengangkatan sebagian GCMN dilakukan dengan metode dermabrasi, kuretase, eksisi tangensial, peeling kimiawi, dan laser (James et al, 2016; Jewargikar et al, 2015; Sakhiya et al, 2020; Wu et al, 2020). Dermabrasi dan kuretase merupakan prosedur yang paling efektif jika dilakukan di 2 hingga 6 minggu pertama kehidupan. Dermabrasi bisa dilakukan untuk mengangkat nevus, namun tidak dapat untuk menangani hipertrikosis. Hal yang harus diperhatikan dalam dermabrasi adalah prosedurnya memerlukan anestesi umum, risiko terjadinya infeksi, dan adanya risiko kerusakan jaringan. Prosedur kuretase juga dilaporkan memuaskan, namun tetap memerlukan anestesi umum, dan adanya risiko timbulnya skar hipertrofi, infeksi, dan hiperpigmentasi (Viana et al, 2013).

Peeling kimiawi dapat digunakan untuk GCMN yang letaknya superfisial. RuizMaldonado dkk menggunakan fenol untuk pasien yang tidak mau atau kontraindikasi prosedur bedah. Peeling dilakukan dalam beberapa kali untuk menghindari efek toksik fenol pada jantung dan ginjal. Komplikasi yang didapatkan berupa skar dan adanya infeksi sekunder. Trichloroacetic acid (TCA) 50\% digunakan untuk depigmentasi pada penelitian ini. Penanganan GCMN dengan laser masih kontroversial. Laser yang bisa digunakan adalah ruby, Q-switched, dan laser karbon dioksida (bisa dikombinasi dengan laser $Q$ - 
switched ruby, atau Nd:YAG) (James et al, 2016; Jewargikar et al, 2015; Sakhiya et al, 2020; Viana et al, 2013). Walaupun penanganan dengan laser ini dapat memperbaiki lesi secara estetik dan mengurangi jumlah sel melanositik, namun pseudomelanoma dapat timbul sebagai penyulit terapi laser (Wolff et al, 2012). Repigmentasi juga dapat ditemukan (Abubakar et al, 2018; Viana et al, 2013).

Pasien dan keluarga harus diberi edukasi untuk melakukan pemeriksaan sendiri terkait lesi kulitnya, dan melaporkan jika ada perubahan dalam warna, bentuk, permukaan, dan jika ada keluhan lainnya. Pemantauan pasien baik jika dilakukan dari berbagai disiplin ilmu, yaitu dermatologi, bedah plastik, radiologi, psikologi, dan neurologi, jika diperlukan. Pasien juga perlu dilakukan pemeriksaan palpasi pada lesi dan kelenjar getah bening. Pengambilan foto lesi kulit diperlukan untuk melakukan pemantauan (Balomenou et al, 2019; Viana et al, 2013; Wolff et al, 2012).

Tidak ada pencegahan yang dapat dilakukan agar terhindar dari nevus kongenital. Mutasi yang diakibatkan radiasi sinar UV tidak dapat dibuktikan menjadi penyebab karena lesi sudah tampak sejak lahir. Peranan pajanan sinar UV dengan timbulnya melanoma secara sekunder belum dapat dibuktikan dengan jelas. Meskipun demikian, lebih baik jika melindungi lesi kulit dari paparan sinar UV yang tidak diperlukan (Wolff et al, 2012).

\section{KESIMPULAN}

Dari hasil anamnesis dan pemeriksaan fisik pada kasus ini, dapat ditarik simpulan bahwa pasien menderita Giant Congenital Melanocytic Nevi (GCMN). Pada kasus ini tidak ditemukan gejala NCM, namun perlu dilakukan pemeriksaan lebih lanjut mengingat pasien mendapat GCMN di area kepala, dan terdapat lesi satelit pada pasien. Pasien juga harus dilakukan observasi secara rutin terhadap kemungkinan terjadinya melanoma. Pasien dan keluarganya harus diberi edukasi untuk melakukan pemeriksaan sendiri terkait lesi kulitnya, dan melaporkan jika ada perubahan terhadap lesi kulitnya.

\section{DAFTAR PUSTAKA}

Abubakar Y, Ahmad HR, and Faruk JA, 2018.

Giant Congenital Melanocytic Nevi: Case Report and Review of Literature. Sub-Saharan African Journal of Medicine. 5 (4): 138141.

Araujo C, Resende C, Pardal F, and Brito C, 2015. Giant Congenital Melanocytic Nevi and Neurocutaneous Melanosis. Case Reports in Medicine. 2015: 1-6. 
Balomenou F, Palianopoulos T, Drougia A, and Giapros V, 2019. Congenital Melanocytic Nevus: A Case Study and Review of the Literature. Journal of Case Reports. 9 (1): $67-$ 69.

Endomba FT, Mbega CR, Tochie JN, and Petnga SJN, 2018. Giant congenital melanocytic nevus in a Cameroonian child: A case report. Journal of Medical Case Reports. 12 (175): 1-4.

Griffiths CEM, Barker J, Bleiker T, Chalmers R, and Creamer D, 2016. Congenital Naevi and other Developmental Abnormalities Affecting the Skin. Rook's Textbook of Dermatology $9^{\text {th }}$ ed. Blackwell Publishing, Oxford. 75.975.15 .

Habif TP, 2004. Nevi and Malignant Melanoma. Clinical Dermatology: A Color Guide to Diagnosis and Therapy $6^{\text {th }}$ ed. Mosby, Edinburgh. 858-861.

Hong SN, Huu ND, Duy NN, Trong TT, Bac $\mathrm{HN}$, et al, 2019. Serial Excision for the Treatment of Giant Congenital Melanocytic Nevus: The Vietnamese Way. Open Access Macedonian Journal of Medical Sciences. 7 (2): 231-233.
James WD, Berger TG, and Elston DM, 2016. Melanocytic Nevi and Neoplasms. Andrews' Diseases of the Skin Clinical Dermatology $12^{\text {th }}$ ed. Elsevier, Philadelphia. 685-686.

Jewargikar R, Andola SK, and Gupta N, 2015. Giant congenital melanocytic nevus. Indian Journal of Paediatric Dermatology. 16: 214-216.

Meshram GG, Kaur N, and Hura KS, 2018. Giant Congenital Melanocytic Nevi: An Update and Emerging Therapies. Case Reports in Dermatology. 10: 24-28.

Sakhiya J, Sakhiya D, Patel M, and Daruwala F, 2020. Giant Congenital Melanocytic Nevi Successfully Treated with Combined Laser Therapy. Indian Dermatology Online Journal. 11: 79-82.

Viana $A C L$, Gontijo $B$, and Bittencourt FV, 2013. Giant congenital melanocytic nevus. An Bras Dermatol. 88 (6): 863-878.

Wolff K, Goldsmith LA, Katz SI, Gilchrest BA, Paller AS, et al, 2012. Benign neoplasias and hiperplasias of melanocyte. Fitzpatrick's Dermatology in General Medicine $8^{\text {th }}$ ed. McGraw Hill, New York. 1377-1382. 
ISSN 1978-2071 (Print); ISSN 2580-5967 (Online) Jurnal IImiah Kedokteran Wijaya Kusuma 10(1): 112-122, Maret 2021

Wolff K, Johnson RA, and Saavedra AP, 2013. Melanoma Precursors and Primary Cutaneous Melanoma. Fitzpatrick's Color Atlas and Synopsis of Clinical Dermatology $7^{\text {th }}$ ed. McGraw Hill, New York. 253-255.
Wu M, Yu Q, Gao B, Sheng L, Li Q, et al, 2020. A large-scale collection of giant congenital melanocytic nevi: Clinical and histopathological characteristics. Experimental and Therapeutic Medicine. 19: 313318. 